\title{
Tissue level, activation and cellular localisation of TGF- $\beta$ | and association with survival in gastric cancer patients
}

\author{
LJAC Hawinkels', HW Verspaget', W van Duijn', JM van der Zon', K Zuidwijk', FJGM Kubben', JH Verheijen², \\ DW Hommes', CBHW Lamers' and CFM Sier*,I
}

'Department of Gastroenterology and Hepatology, Leiden University Medical Centre, Leiden, The Netherlands; ${ }^{2}$ TNO Quality of Life BioSciences, Leiden, The Netherlands

Transforming growth factor- $\beta$ I (TGF- $\beta$ I), a tumour suppressing as well as tumour-promoting cytokine, is stored as an extracellular matrix-bound latent complex. We examined TGF- $\beta$ I activation and localisation of TGF- $\beta$ | activity in gastric cancer. Gastric tumours showed increased stromal and epithelial total TGF- $\beta$ I staining by immunohistochemistry. Active TGF- $\beta$ I was present in malignant epithelial cells, but most strongly in smooth muscle actin expressing fibroblasts. Normal gastric mucosa from the same patient showed some staining for total, and little for active TGF- $\beta$ I. Active TGF- $\beta$ | levels were determined by ELISA on tissue homogenates, confirming a strong increase in active TGF- $\beta$ I in tumours compared to corresponding normal mucosa. Moreover, high tumour TGF$\beta \mid$ activity levels were significantly associated with clinical parameters, including worse survival of the patients. Total and active TGF$\beta$ । levels were not correlated, suggesting a specific activation process. Of the different proteases tested, active TGF- $\beta$ । levels were only correlated with urokinase activity levels. The correlation with urokinase activity suggests a role for plasmin in TGF- $\beta$ I activation in the tumour microenvironment, resulting in transformation of resident fibroblasts to tumour promoting myofibroblasts. In conclusion we have shown localisation and clinical relevance of TGF- $\beta$ | activity levels in gastric cancer.

British Journal of Cancer (2007) 97, 398-404. doi:I0.I038/sj.bjc.6603877 www.bjcancer.com

Published online 17 July 2007

(c) 2007 Cancer Research UK

Keywords: transforming growth factor- $\beta$; matrix metalloproteinase; ELISA; fibroblast; tumour microenvironment; immunohistochemistry

Transforming growth factor- $\beta$ (TGF- $\beta$ ) is a multifunctional cytokine, which influences cell differentiation, proliferation, motility and apoptosis (Akhurst and Derynck, 2001; Elliott and Blobe, 2005). Among the TGF- $\beta$ family, which comprises TGF- $\beta 1$, $-\beta 2$ and $-\beta 3$, TGF- $\beta 1$ is most abundantly expressed, especially in various pathological conditions including chronic inflammatory diseases (Marek et al, 2002) and cancer (Tsushima et al, 1996; Akhurst and Derynck, 2001; Elliott and Blobe, 2005; Bierie and Moses, 2006). Transforming growth factor- $\beta 1$ has been shown to reduce the immune response (Beck et al, 2001), stimulate angiogenesis (Choi et al, 1997; Derynck et al, 2001; Bertolino et al, 2005), increase synthesis of proteolytic enzymes (Seomun et al, 2001; Kim et al, 2004) and stimulate extra cellular matrix (ECM) deposition (Cheng and Lovett, 2003) in the tumour microenvironment.

Several studies examined the role of TGF- $\beta 1$ in gastric cancer. Studies on TGF- $\beta 1$ mRNA showed expression in both normal and tumour tissue, but levels in gastric tumours were strongly upregulated (Naef et al, 1997; Park et al, 2002). Immunohistochemical studies showed TGF- $\beta$ expression in tumour cells (Naef et al, 1997; Park et al, 1997; Maehara et al, 1999; Saito et al, 1999) and sporadic in fibroblasts (Naef et al, 1997). Positive TGF- $\beta 1$

\footnotetext{
* Correspondence: Dr CFM Sier, Department of Gastroenterology and Hepatology, Building I, C4, Leiden University Medical Centre, PO Box 9600, 2300 RC Leiden, The Netherlands; E-mail: c.f.m.sier@lumc.nl Received 28 March 2007; revised I 4 June 2007; accepted I4 June 2007; published online 17 July 2007
}

immunostaining was found to be related to invasion and metastasis of gastric cancer (Nakamura et al, 1998; Maehara et al, 1999). Finally, gastric cancer patients showed strongly increased tissue TGF- $\beta 1$ levels and, unexpectedly, reduced serum TGF- $\beta 1$ levels (Park et al, 1997).

Transforming growth factor- $\beta 1$ is synthesised as an inactive precursor, the large latent complex consisting of a TGF- $\beta$ dimer, the latency-associated protein (LAP) and latent TGF- $\beta$ binding protein (LTBP) for localisation and binding to the ECM (Mazzieri et al, 2005). Before TGF- $\beta 1$ can exert its biological effects, LAP and LTBP have to be dissociated. This can occur by conformational changes (Murphy-Ullrich and Poczatek, 2000; Annes et al, 2003; Asano et al, 2006), proteolytic cleavage (Lyons et al, 1990; Taipale et al, 1992; Dallas et al, 2002; Wang et al, 2006), irradiation (Barcellos-Hoff et al, 1994; Ehrhart et al, 1997) or by an acid environment (Jullien et al, 1989). The complex release mechanism of TGF- $\beta 1$ might implicate that high total TGF- $\beta 1$ has no biological consequences without the presence of appropriate activation mechanisms in the tumour microenvironment. Therefore, measuring TGF- $\beta 1$ activity levels and the localisation in cancer could be more informative regarding the state of cancer progression.

We studied cellular localisation and levels of active TGF- $\beta 1$ and the activation process in gastric cancer. We used an ELISA, which specifically detects active TGF- $\beta 1$, to examine endogenously active as well as total (acid-activated) TGF- $\beta 1$ levels in gastric cancer tissue and showed cellular localisation of active TGF- $\beta 1$ by immunohistochemical staining. To study the activation process, tissue levels of several proteases, putatively involved in the 
activation process, were determined and analysed for correlations with TGF- $\beta 1$ activity levels.

\section{MATERIALS AND METHODS}

\section{Patient population}

Fresh tissue specimens from a total of 51 patients (34 $\hat{\delta}, 17 q$ ) undergoing resection for primary gastric adenocarcinoma at the department of Oncologic Surgery, Leiden University Medical Centre, were collected as described before (Kubben et al, 2006). Patient characteristics and clinicopathological parameters are shown in Table 1. Tissue specimens were homogenised in Tris/ Tween- 80 buffer, and protein concentrations were determined as described previously (Sier et al, 1996).

\section{ELISA for total and active TGF- $\beta 1$}

The levels of total and active TGF- $\beta$ were measured using a human TGF- $\beta 1$ duo-set (DY240) with a substrate reagent pack (DY999) according to the manufacturers' instructions (both R\&D Systems Europe, Abingdon, UK). This ELISA specifically detects active TGF- $\beta 1$ and does not cross-react with other subtypes of TGF- $\beta$.

Table I Median levels ${ }^{\mathrm{a}}$ of total and active TGF- $\beta$ I in gastric carcinomas in relation to clinicopathological parameters

\begin{tabular}{|c|c|c|c|c|c|c|c|}
\hline & & \multicolumn{3}{|c|}{ Active TGF- $\beta$ I } & \multicolumn{3}{|c|}{ Total TGF- $\beta$ I } \\
\hline & $n$ & Median & Range & $P$-value & Median & Range & $P$-value \\
\hline \multicolumn{8}{|l|}{ Age } \\
\hline$<66$ years & 26 & 17.6 & $1.8-81.3$ & & 231.1 & $51.7-620.1$ & \\
\hline$>66$ years & 25 & 15.9 & $1.6-46.2$ & 0.510 & 292.3 & $21.1-619.8$ & 0.763 \\
\hline \multicolumn{8}{|l|}{ Laurén } \\
\hline $\begin{array}{l}\text { Diffuse/ } \\
\text { mixed }\end{array}$ & 17 & 18.7 & $1.8-55.4$ & & 206.8 & $52.0-592.3$ & \\
\hline Intestinal & 34 & 16.6 & $1.6-81.3$ & 0.460 & 284.7 & $21.1-620.1$ & 0.238 \\
\hline \multicolumn{8}{|l|}{ Differentiation } \\
\hline Well & 21 & 15.5 & $1.8-55.4$ & & 214.2 & $52.0-620.0$ & \\
\hline $\begin{array}{l}\text { Moderate/ } \\
\text { poor }\end{array}$ & 28 & 17 & $1.6-81.3$ & 0.824 & .5 & $21.1-620.1$ & 0.303 \\
\hline \multicolumn{8}{|l|}{ TNM } \\
\hline I & 14 & 15.8 & $8.7-81.3$ & & 196.8 & $21.1-341.4$ & \\
\hline$\|-I V$ & 37 & 18.1 & $1.6-71.0$ & 0.688 & 292.8 & $62.2-620.1$ & 0.010 \\
\hline \multicolumn{8}{|l|}{ Localization } \\
\hline Cardia & 22 & 18.9 & $1.6-81.3$ & & 277.5 & $51.7-620.1$ & \\
\hline Rest & 29 & 13.9 & $1.8-46.2$ & 0.050 & 214.2 & $21.1-619.8$ & 0.555 \\
\hline \multicolumn{8}{|l|}{ Diameter } \\
\hline$<6 \mathrm{~cm}$ & 30 & 16.6 & $3.2-46.2$ & & 205.7 & $21.1-534.8$ & \\
\hline$>6 \mathrm{~cm}$ & 21 & 17.9 & $1.6-81.3$ & 0.954 & 362.2 & $62.2-620.1$ & 0.004 \\
\hline \multicolumn{8}{|l|}{ Invasion } \\
\hline Subserosa & 34 & 19.1 & $1.6-81.3$ & & 221.3 & $21.1-620.1$ & \\
\hline Further & 17 & 11.4 & $3.2-42.4$ & 0.034 & 367.4 & $63.4-619.8$ & 0.093 \\
\hline \multicolumn{8}{|l|}{ Inflammation } \\
\hline Non/mild & 43 & 15.9 & $1.6-55.4$ & & 274.6 & $21.1-619.8$ & \\
\hline Severe & 7 & 23.9 & $11.4-81.3$ & 0.010 & 296.2 & $132.1-620.1$ & 0.546 \\
\hline \multicolumn{8}{|l|}{ Status $^{b}$} \\
\hline Alive & 17 & 13.9 & $1.8-46.2$ & & 209.5 & $21.1-385.0$ & \\
\hline Deceased & 34 & 18.8 & $1.6-81.3$ & 0.208 & 286.3 & $51.7-620.1$ & 0.215 \\
\hline
\end{tabular}

TGF- $\beta 1=$ Transforming growth factor- $\beta$ ।; TNM, tumour node metastasis classification. ${ }^{\mathrm{a}}$ Median and range in picogram per milligram protein. ${ }^{\mathrm{b}}$ Tumour-associated death. Bold $P$-values are considered significant.
Total TGF- $\beta 1$ levels were determined by acid activation $(1 \mathrm{M}$ hydrochloric acid, $30 \mathrm{~min}$, room temperature) of the latent TGF- $\beta 1$ in the homogenate. Untreated and activated $(30 \mu \mathrm{l})$ samples from the same homogenate were assayed in parallel.

Assays for urokinase, urokinase receptor, plasminogen activator inhibitors, matrix metalloproteinases and tissue inhibitors of matrix metalloproteinases

Total antigen levels of urokinase plasminogen activator (uPA), plasminogen activator inhibitors (PAI-1 and -2), urokinase plasminogen activator receptor, matrix metalloproteinases (MMP-2, -7, -8, -9) and tissue inhibitors of matrix metalloproteinases (TIMP-1 and -2) were determined using previously described ELISAs (Ganesh et al, 1994; Sier et al, 1994; Hanemaaijer et al, 1998; Kubben et al, 2006). The bioactivity assays for uPA, MMP-2 and MMP-9 were performed as described before (Hanemaaijer et al, 1998; Sier et al, 2000; Kubben et al, 2006).

\section{Immunohistochemistry}

Tissue samples from the same tumours as used for homogenates were formalin fixed, dehydrated and embedded in paraffin. For cryosections, unfixed tissue was embedded in OCT (Sakura Finetek Europe BV, Zoeterwoude, The Netherlands) and snap-frozen in liquid nitrogen. Paraffin sections $(5 \mu \mathrm{m})$ were deparaffinised, blocked in $0.3 \%$ hydrogen peroxide $\left(\mathrm{H}_{2} \mathrm{O}_{2}\right)$ in methanol for $20 \mathrm{~min}$ and rehydrated through graded alcohol. Antigen retrieval was performed by boiling in a $0.01 \mathrm{M}$ citrate solution $(\mathrm{pH}$ 6.0) for $10 \mathrm{~min}$ in a microwave oven. After being rinsed in phosphatebuffered saline (PBS), the sections were incubated with the primary antibodies (in PBS/1\% bovine serum albumin (BSA)): mouse anti-pan-cytokeratin $(1: 1000$, clone C11, Santa Cruz Biotechnologies, Santa Cruz, CA, USA), mouse anti-vimentin ( $1: 400$, clone V9, Santa Cruz Biotechnologies), mouse anti-smooth muscle actin (anti-SMA; $1: 1000$, clone ASM-1, Progen, Heidelberg, Germany), mouse anti-TGF- $\beta 1$ (1:1000, Anogen, Mississauga, Ontario, Canada) or rabbit anti-phospho-smad-2 (p-smad-2; $1: 1000$, kindly provided by Professor/Dr P ten Dijke; Persson et al, 1998) overnight at room temperature. After washing, the sections were incubated with biotinylated goat anti-mouse $(1: 200)$ or goat anti-rabbit (1:400, both Dako, Glostrup, Denmark) secondary antibodies (in $\mathrm{PBS} / 1 \% \mathrm{BSA}$ ) for $30 \mathrm{~min}$, followed by washing and incubation with streptavidin-avidin-biotin complex/HRP (Dako) for $30 \mathrm{~min}$. The brown colour was developed by $0.004 \% \mathrm{H}_{2} \mathrm{O}_{2}$ (Merck, Darmstadt, Germany) and 0.05\% diaminobenzidine tetrahydrochloride (Sigma, Schnelldorf, Germany) in $0.01 \mathrm{~m}$ Tris $-\mathrm{HCl} \mathrm{pH} 7.6$ for $10 \mathrm{~min}$. The slides were counterstained with Mayer's haematoxylin (Merck) except for the p-smad-2 staining, which were shortly counterstained with methyl green, diluted in $0.1 \mathrm{~m}$ sodium acetate buffer $\mathrm{pH}$ 4.2. Sections were dehydrated and mounted in entellan (Merck).

Frozen sections $(4 \mu \mathrm{m})$ were fixated in ice-cold acetone (10 min), washed with PBS and incubated overnight $\left(4^{\circ} \mathrm{C}\right)$ with the primary antibodies described below: anti-pan-cytokeratin (1:16000), antivimentin $(1: 800)$, mouse anti-SMA $(1: 2000)$, rabbit anti-active TGF- $\beta 1$ ( $1: 800$, Promega, Madison, WI, USA) or phospho-smad-2 antibody $(1: 800)$. Further, the sections were treated as described above and were counterstained with Mayer's haematoxylin. Negative control sections were included by omitting the primary antibodies.

Photomicrographs of representative sections were taken with a Leica DMLB microscope equipped with a Leica DC500 camera.

\section{Statistical analysis}

Differences between normal and tumour values were calculated using the Mann-Whitney $U$-test. For survival analyses, the clinicopathological parameters were dichotomised as described 
before (Sier et al, 1996). Cutoff values for TGF- $\beta 1$ were optimised using ROC analyses. Multivariate survival analyses were performed with the Cox proportional hazards method by separately adding variables to the dichotomised clinicopathological parameters. Survival curves were constructed using the method of Kaplan and Meier including log-rank tests. Differences were considered significant when $P \leqslant 0.05$. The analyses were performed using the SPSS statistical package (Release 12.01, SPSS Inc., Chicago, IL, USA).

\section{RESULTS}

\section{Tissue TGF- $\beta 1$ levels and clinicopathological characteristics}

Active TGF- $\beta 1$ was detectable in all 51 tumour homogenates with concentrations of $1.6-81.3 \mathrm{pg} \mathrm{mg}^{-1}$ protein. Total TGF- $\beta 1$ levels ranged from 21.1 to $620.1 \mathrm{pg} \mathrm{mg}^{-1}$ protein. Active and total TGF$\beta 1$ levels were significantly $(P<0.0001)$ increased in gastric cancer tissue compared with adjacent normal tissues $(n=20$; Figure $1 \mathrm{~A}$ and B). ROC analyses revealed that total as well as active TGF- $\beta 1$ were good diagnostic discriminators between normal and tumour tissue with AUC values of, respectively, $0.91(P=0.03)$ and 0.82 $(P=0.05)$. Tumour levels of active TGF- $\beta 1$ did not correlate significantly with total levels $(\rho=0.255 ; P=0.071, n=51)$, indicating that the amount of active form is not dependent on the total TGF- $\beta 1$ pool present. The correlation of TGF- $\beta 1$ levels with clinicopathological parameters is presented in Table 1 . Active TGF- $\beta 1$ levels were significantly increased in tumours localised in the cardia, in tumours with invasion limited to the subserosa and in tumours with a high inflammation grade. Total TGF- $\beta 1$ levels were enhanced in tumours with high tumour node metastasis (TNM) classification or large diameter.

\section{Cellular localisation of active and total TGF- $\beta 1$ in gastric cancer}

To determine the cellular localisation of active TGF- $\beta 1$ in gastric cancer, we stained frozen sections for active TGF- $\beta 1$ (Figure $2 \mathrm{~A}$ ). To confirm the staining being representative for TGF- $\beta 1$ activity, sections were also stained for phosphorylated smad-2 (p-smad-2), indicating TGF- $\beta$ signalling and therefore the presence of active TGF- $\beta$ (Massague et al, 2005; Blaney Davidson et al, 2006) (Figure 2B). Nuclear localisation of p-smad-2 in myofibroblasts and in malignant cells is shown in Figure 2 panels B1 and B2, respectively.

Staining for both TGF- $\beta 1$ and p-smad- 2 was most pronounced in vimentin-positive (Figure 2D) and SMA-positive (Figure 2E)
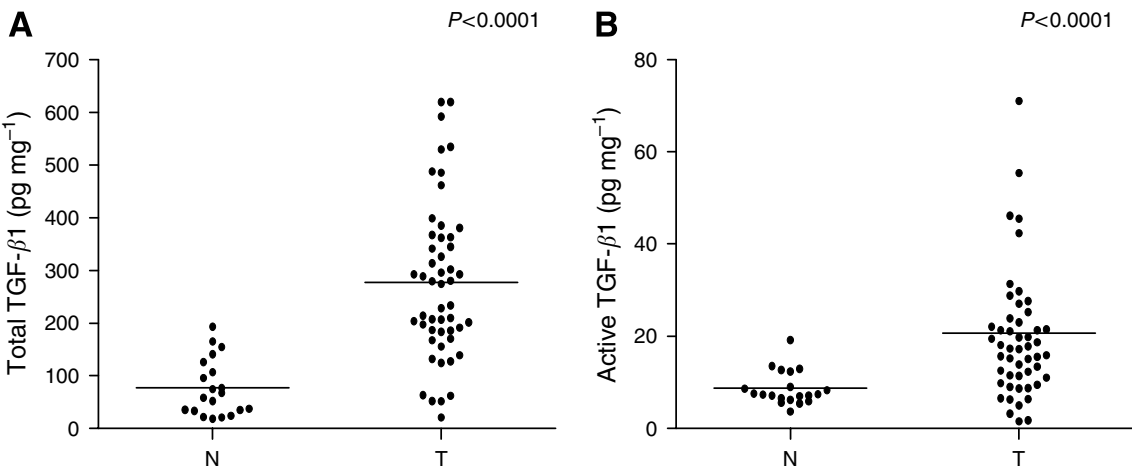

Figure I Total and active TGF- $\beta$ | levels in tumour and corresponding normal tissue homogenates. Total $(\mathbf{A})$ and active (B) TGF- $\beta$ I levels are significantly upregulated in tumours $(\mathrm{T})$ compared to corresponding normal $(\mathrm{N})$ tissue (both $P<0.000 \mathrm{I}$ ).
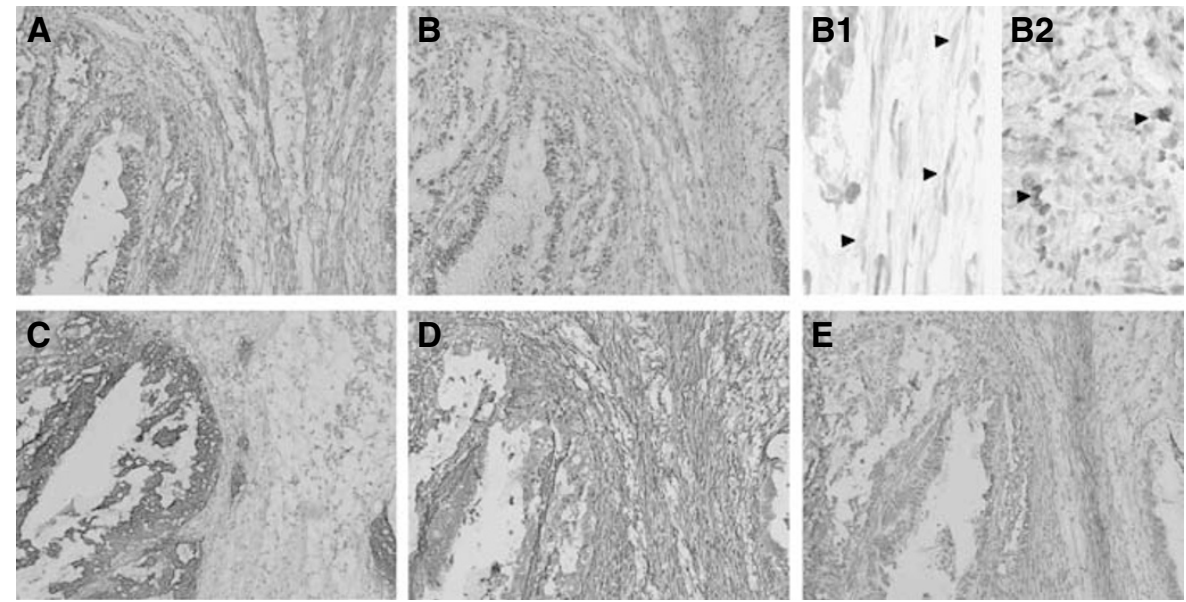

Figure 2 Cellular localisation of active TGF- $\beta$ I in gastric cancer. Immunohistochemical staining of gastric carcinomas (sequential frozen sections). Staining pattern for active TGF- $\beta$ I (A) corresponds to phospho-smad-2 staining (B). Inserts BI and B2 show nuclear localisation (arrowheads) of p-smad-2 in the myofibroblasts and malignant cells, respectively. As shown by staining for pan-cytokeratin (C, epithelial marker), vimentin (Vim, D, mesenchymal marker) and SMA (E, smooth muscle/myofibroblast marker), TGF- $\beta$ I activity is observed in malignant cells and in Vim +/SMA + cells (myofibroblasts). Magnification $\times 200,-B 1-B 2 \times 630$ 
myofibroblasts and in pan-cytokeratin-positive malignant cells (Figure 2C). As, in our hands, staining for total TGF- $\beta 1$ was not detectable on frozen sections from gastric cancer specimens, we stained 10 paraffin-embedded tissue sections from the abovedescribed patient group. Tumours showed strongly increased epithelial and stromal staining for total TGF- $\beta 1$ (Figure $3 \mathrm{C}$ ) compared to normal gastric mucosa (Figure 3A). Active TGF- $\beta 1$, represented by p-smad-2 staining (Figure 3D, staining for active TGF- $\beta 1$ was not applicable to paraffin sections), was increased in both epithelial as well as stromal cells compared to little staining in normal tissue (Figure 3B).

Figure $3 \mathrm{E}-\mathrm{G}$ illustrates the association between active TGF- $\beta 1$ ELISA data and the p-smad-2 immunohistochemical staining, indicating TGF- $\beta$ activity. Three carcinomas with decreasing active TGF- $\beta 1$ tissue levels (high, median and low) were stained for p-smad-2 showing decreased nuclear staining for p-smad-2 in the malignant cells and even stronger in the SMA-positive myofibro- blasts (SMA, vimentin and pan-cytokeratin staining on sequential sections, not shown).

\section{Prognostic relevance tissue TGF- $\beta 1$ levels}

Kaplan-Meier survival curves, using tertiles (cutoff values $<12.56$; $12.56-21.28$; $>21.28 \mathrm{pg}$ TGF- $\beta 1 \mathrm{mg}^{-1}$ protein; Figure $4 \mathrm{~A}$ ) or quartiles (not shown), showed a stepwise correlation for active and total TGF- $\beta 1$ levels with tumour-associated survival. Because of the small group size, the patients were dichotomised for active and total TGF- $\beta 1$ using ROC-based optimal cutoff values (15 (active) and 400 (total) pg TGF- $\beta 1 \mathrm{mg}^{-1}$ protein, respectively) for further analyses. High tumour levels of active and total TGF- $\beta 1$ were significantly correlated with worse survival (log rank 4.88, $P=0.027$ and $\log$ rank $3.96, P=0.047$, respectively). Figure $4 \mathrm{~B}$ shows a Kaplan-Meier curve, presenting a combination of either high total or high active TGF- $\beta 1$, which resulted in a higher

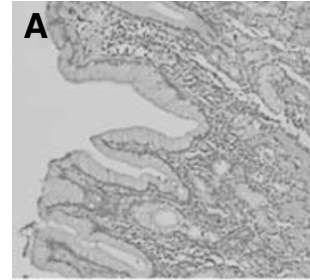

B
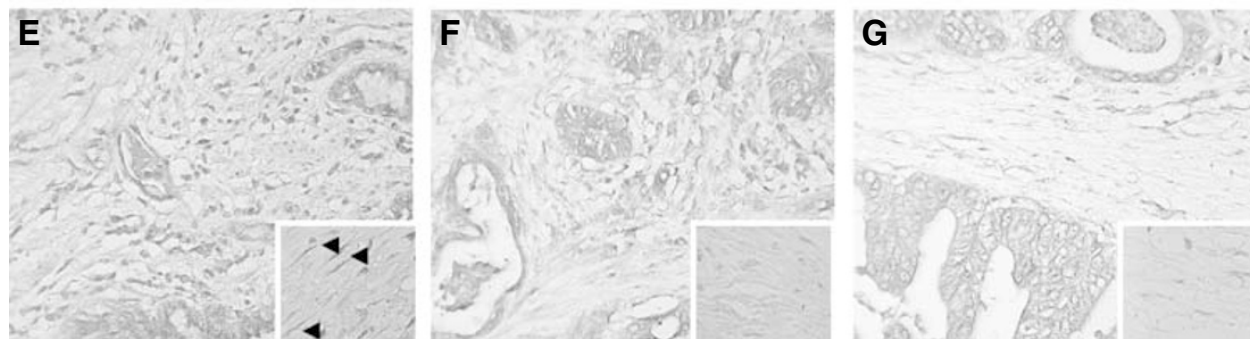

Figure 3 Total TGF- $\beta$ and p-smad-2 staining on paraffin-embedded gastric cancer tissue sections. Staining on normal gastric mucosa shows some staining for total TGF- $\beta(\mathbf{A})$ and almost no staining for p-smad-2 (B, insert $\times 400)$. Both are strongly increased in corresponding tumour tissue $(\mathbf{C}$, total TGF- $\beta$ I; $\mathbf{D}$, p-smad-2, insert $\times 400)$. (E-G) p-smad 2 staining in three different gastric carcinomas with high $\left(81.3 \mathrm{pg} \mathrm{mg}^{-1}, \mathbf{E}\right), \mathrm{median}^{-1}\left(2 \mathrm{l}\right.$. I pg mg $\left.{ }^{-1}, \mathbf{F}\right)$ and low active TGF- $\beta$ | levels $\left(1.6 \mathrm{pg} \mathrm{mg}^{-1}, \mathbf{G}\right)$. A strong decrease in nuclear staining (inserts $\mathbf{E}-\mathbf{G}$, magnification $\times 630$, arrowheads indicate intense nuclear staining in myofibroblasts in E) is observed especially in myofibroblasts (staining for pan-cytokeratin, vimentin and SMA on sequential sections, not shown). Magnification $\times 200$.
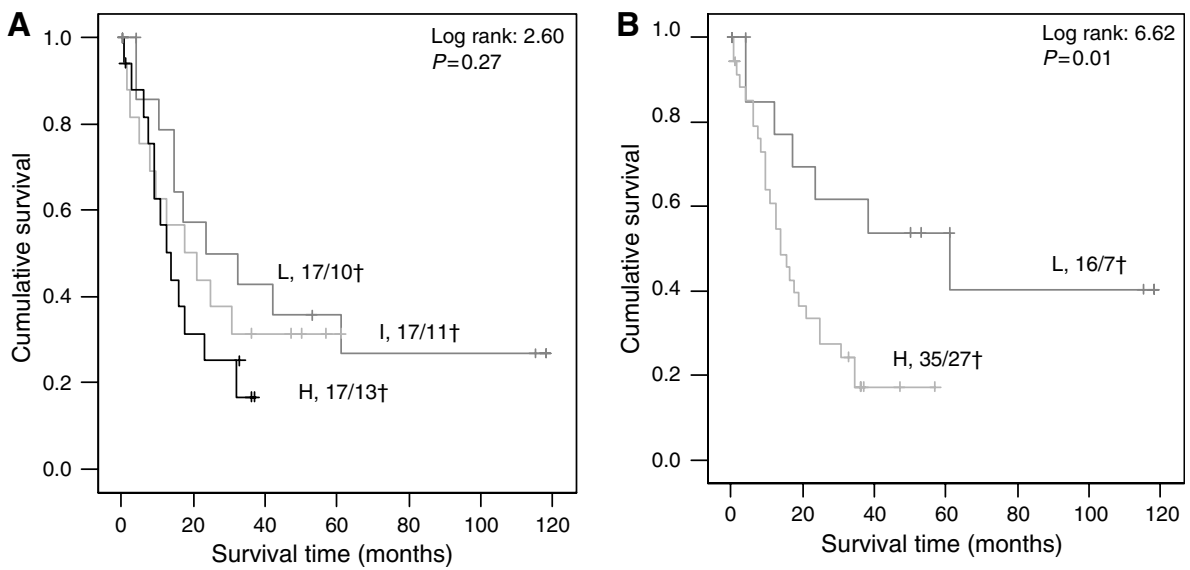

Figure 4 Kaplan-Meier survival analysis for tumour TGF- $\beta$ | tissue levels. (A) Kaplan-Meier analysis showed a stepwise decrease in survival for patients

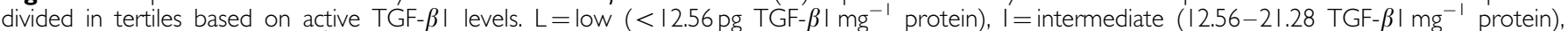
$\mathrm{H}=$ high (>21.28 TGF- $\beta 1 \mathrm{mg}^{-1}$ protein), $x / y \dagger=$ number of patients/number of patients deceased. (B) Kaplan-Meier analysis showed a significant shorter survival for patients with either high active or high total TGF- $\beta$ | tissue levels. $\mathrm{L}=$ low (active TGF- $\beta|<| 5 \mathrm{pg}$ TGF- $\beta \mid \mathrm{mg}^{-1}$ protein or total TGF- $\beta$ $<400 \mathrm{pg} \mathrm{ml}^{-1}$ ) and $\mathrm{H}=$ high (active TGF- $\beta$ I $>15 \mathrm{pg}$ TGF- $\beta 1 \mathrm{mg}^{-1}$ protein or total TGF- $\beta>400 \mathrm{pg} \mathrm{ml}{ }^{-1}$ ). 
Table 2 Uni- and multivariate Cox's proportional hazards analyses of total and active TGF- $\beta$ I levels in relation to tumour-associated survival of 5 I gastric cancer patients

\begin{tabular}{|c|c|c|c|c|c|c|}
\hline \multirow[b]{2}{*}{ Parameter } & \multicolumn{3}{|c|}{ Univariate } & \multicolumn{3}{|c|}{ Multivariate } \\
\hline & HR & Cl $95 \%$ & $P$-value & HR & Cl $95 \%$ & $P$-value \\
\hline Age & 1.258 & $0.637-2.484$ & 0.509 & 1.584 & $0.662-2.716$ & 0.240 \\
\hline Laurén classification & 0.699 & $0.348-1.402$ & 0.313 & 0.932 & $0.348-1.402$ & 0.865 \\
\hline Differentiation & 1.953 & $0.906-4.208$ & 0.088 & 1.866 & $0.906-4.208$ & 0.195 \\
\hline TNM classification & 2.755 & $1.057-7.179$ & 0.038 & 1.534 & $1.057-7.179$ & 0.440 \\
\hline Tumour localization & 2.379 & $1.092-5.180$ & 0.029 & 1.916 & $1.092-5.180$ & 0.151 \\
\hline Total TGF- $\beta$ I & 2.234 & $0.979-5.098$ & 0.056 & 1.796 & $0.753-4.287$ & 0.187 \\
\hline Active TGF- $\beta$ I & 2.339 & $1.065-5.138$ & 0.034 & 2.125 & $0.934-4.836$ & 0.072 \\
\hline High total/high active TGF- $\beta$ | & 3.108 & $1.240-7.788$ & 0.016 & 2.763 & $1.061-7.199$ & 0.037 \\
\hline
\end{tabular}

Description of variables is shown in Table I. Bold $P$-values are considered significant.

Table 3 Spearman's correlations between the levels of total and active TGF- $\beta$ I and various proteinases and proteinase inhibitors in 51 gastric cancer homogenates

\begin{tabular}{|c|c|c|c|c|c|}
\hline & \multirow[b]{2}{*}{ Assay } & \multicolumn{2}{|c|}{ Active TGF- $\beta$ I } & \multicolumn{2}{|c|}{ Total TGF- $\beta$ I } \\
\hline & & $\rho$ & $P$-value & $\rho$ & $P$-value \\
\hline UPA & ELISA & 0.202 & 0.163 & 0.259 & 0.072 \\
\hline UPA & $\mathrm{BIA}$ & 0.284 & 0.048 & 0.125 & 0.394 \\
\hline uPAR & ELISA & 0.076 & 0.605 & 0.126 & 0.389 \\
\hline PAI-I & ELISA & 0.195 & 0.185 & 0.198 & 0.176 \\
\hline PAI-2 & ELISA & -0.181 & 0.219 & -0.210 & 0.151 \\
\hline MMP-2 & ELISA & 0.219 & 0.149 & 0.296 & 0.048 \\
\hline MMP-2 & $\mathrm{BIA}$ & 0.253 & 0.111 & -0.060 & 0.709 \\
\hline MMP-7 & ELISA & -0.091 & 0.568 & 0.248 & 0.114 \\
\hline MMP-8 & ELISA & 0.717 & 0.240 & 0.111 & 0.449 \\
\hline MMP-9 & ELISA & 0.023 & 0.878 & 0.082 & 0.579 \\
\hline MMP-9 & $\mathrm{BIA}$ & 0.121 & 0.424 & 0.268 & 0.071 \\
\hline TIMP-I & ELISA & -0.039 & 0.821 & 0.045 & 0.794 \\
\hline TIMP-2 & ELISA & -0.209 & 0.221 & -0.064 & 0.711 \\
\hline
\end{tabular}

$\mathrm{PAI}=$ plasminogen activator inhibitor: TIMP $=$ tissue inhibitor of matrix metalloproteinase; $\mathrm{uPA}=$ urokinase plasminogen activator; $\mathrm{UPAR}=$ urokinase plasminogen activator receptor. ELISA, total antigen level; BIA, activity level. Bold P-values are considered significant.

significance value, confirming the independence of both parameters. To evaluate the validity of the chosen TGF- $\beta 1$ cutoff values, we used the same cutoff values again for the group including 29 more recently collected gastric cancer patients, where active TGF$\beta 1$ kept its prognostic significance and the hazard ratio increased ( $n=80$, HR $6.09, P=0.014$ ). The prognostic value of TGF- $\beta 1$ was further evaluated using Cox proportional hazard analyses (Table 2). Particularly active TGF- $\beta 1$ and the combined TGF- $\beta 1$ levels were statistically significantly correlated with survival. In multivariate analysis with the clinicopathological parameters (Table 2), the combined TGF- $\beta 1$ level remained statistically significant in multivariate tests.

\section{Proteolytic TGF- $\beta 1$ activation}

Because TGF- $\beta 1$ is at least partly activated by proteolytic cleavage, we evaluated the total and active TGF- $\beta 1$ levels for correlations with likely candidate proteinases involved in TGF- $\beta 1$ activation and with PAI- 1 , a presumed secondary marker of TGF- $\beta 1$ activity, in the gastric cancer homogenates (Table 3 ). Total TGF- $\beta 1$ levels showed significant correlation only with total MMP-2 antigen levels, whereas active TGF- $\beta 1$ levels only showed statistical significant correlation with urokinase (uPA) activity, not with total uPA protein levels.

\section{DISCUSSION}

Numerous studies have shown the involvement of TGF- $\beta 1$ in different types of cancer, including gastric, colorectal and breast cancer (Naef et al, 1997; Nakamura et al, 1998; Maehara et al, 1999; Saito et al, 1999; Desruisseau et al, 2006). Most of these studies assessed tissue TGF- $\beta 1$ levels by mRNA expression, immunohistochemistry or serum TGF- $\beta 1$ levels, which give either less information on the actual protein levels, are difficult to quantify or do not reflect local effects. A recent study on TGF- $\beta 1$ levels in breast cancer tissue homogenates showed a significant relation of increased tissue total TGF- $\beta 1$ levels with disease-free survival (Desruisseau et al, 2006). In the present study we observed a similar relation of tissue total TGF- $\beta 1$ level with survival of gastric cancer patients. Although upregulation of TGF- $\beta 1$ is common in various types of cancer, it is not commonly regarded as a prognostic factor for survival. This is probably due to the fact that the release of the biologically active TGF- $\beta 1$ from the latent complex is crucial for the involvement of TGF- $\beta 1$ in pathological processes. Active TGF- $\beta 1$ levels have hardly been studied because of the absence of sensitive assays, which specifically detect active TGF- $\beta 1$ in the low concentrations observed in vivo. We optimised an existing ELISA and were able to detect endogenous TGF- $\beta 1$ levels (without acid activation) in all gastric cancer homogenates. Furthermore, the localisation of active TGF- $\beta 1$ in these cancers was shown by immunohistochemical staining for active TGF- $\beta 1$ and its signalling molecule p-smad-2. In a sequential series of tumours with decreasing active TGF- $\beta 1$ levels (ELISA), we also observed strongly decreasing nuclear staining pattern in the myofibroblasts. Active TGF- $\beta 1$ levels showed association with localisation, invasion, inflammation and survival of gastric cancer patients. As expected, the association of active TGF- $\beta 1$ levels with survival was indeed stronger compared to total TGF- $\beta 1$ level. There was no correlation between active and total TGF- $\beta 1$ levels, implying that the activation was not dependent of the total pool latent TGF- $\beta 1$ present in the tumour microenvironment. As a consequence, total TGF- $\beta 1$ levels showed association with other parameters, that is tumour diameter and TNM stage, whereas there was no association of these parameters with active TGF- $\beta 1$ levels.

Localisation of active TGF- $\beta 1$ is observed in inflammatory- and tumour cells and especially in tumour-associated myofibroblasts, implying that increased levels of activated TGF- $\beta 1$, more than overall TGF- $\beta 1$ levels, are associated with accumulation of myofibroblasts in gastric cancer. Indeed, active TGF- $\beta 1$ can induce transdifferentiation from fibroblasts to myofibroblasts in the tumour microenvironment, which show an increased expression of various proteolytic enzymes including MMPs (Dwivedi et al, 2006). In turn, these proteases, including plasmin (George et al, 2005), MMP-2 (Wang et al, 2006), MMP-3 (Maeda et al, 2002) and MMP-13 (D'Angelo et al, 2001), have been shown to be involved in 
TGF- $\beta 1$ activation. In our study we observed a significant relation between active TGF- $\beta 1$ levels and urokinase activity, implying plasmin, via urokinase-mediated plasminogen activation, as a principal candidate of latent TGF- $\beta 1$ activation. The investigated MMPs showed no significant correlations with active TGF- $\beta 1$ levels. For TIMP-1 and -2, we observed a weak negative correlation with TGF- $\beta 1$ activity, also observed in vivo in a recent study (Dasgupta et al, 2006). Total TGF- $\beta 1$ levels only correlated significantly with MMP-2 levels in homogenates. Immunohistochemistry showed TGF- $\beta 1$ activity present in different cell types, probably with different activators in the tumour microenvironment. This explains why in a homogenate it is unlikely that a strong significant association with one specific MMP will be observed.

In conclusion, we have shown that total and active TGF- $\beta 1$ levels are increased in gastric tumour tissue and that both are of prognostic relevance in gastric cancer. Active tissue TGF- $\beta 1$ levels showed association with clinicopathological parameters and with
uPA activity, indicating a possible role for plasmin in TGF- $\beta 1$ activation in gastric cancer. Immunohistochemical studies showed strong expression of active TGF- $\beta 1$ in the myofibroblast population. We propose that increased proteinase activity in the tumour microenvironment leads to increased ECM-bound latent TGF- $\beta 1$ activation, resulting in transformation of resident fibroblasts to tumour promoting myofibroblasts. Further studies on a larger group of patients should be performed to establish the prognostic value of active tissue TGF- $\beta 1$ levels in gastric cancer and further elucidate the mechanism of latent TGF- $\beta 1$ activation.

\section{ACKNOWLEDGEMENTS}

We thank Professor Dr P ten Dijke, Leiden University Medical Centre, Department of Molecular Cell Biology, for supplying the phospho-smad-2 antibody.

\section{REFERENCES}

Akhurst RJ, Derynck R (2001) TGF-beta signaling in cancer-a doubleedged sword. Trends Cell Biol 11: S44-S51

Annes JP, Munger JS, Rifkin DB (2003) Making sense of latent TGFbeta activation. J Cell Sci 116: $217-224$

Asano Y, Ihn H, Yamane K, Jinnin M, Tamaki K (2006) Increased expression of integrin alphavbeta5 induces the myofibroblastic differentiation of dermal fibroblasts. Am J Pathol 168: 499-510

Barcellos-Hoff MH, Derynck R, Tsang ML, Weatherbee JA (1994) Transforming growth factor-beta activation in irradiated murine mammary gland. J Clin Invest 93: $892-899$

Beck C, Schreiber H, Rowley D (2001) Role of TGF-beta in immune-evasion of cancer. Microsc Res Tech 52: 387-395

Bertolino P, Deckers M, Lebrin F, ten Dijke P (2005) Transforming growth factor-beta signal transduction in angiogenesis and vascular disorders. Chest 128: $585 \mathrm{~S}-590 \mathrm{~S}$

Bierie B, Moses HL (2006) Tumour microenvironment: TGFbeta: the molecular Jekyll and Hyde of cancer. Nat Rev Cancer 6: 506-520

Blaney Davidson EN, Vitters EL, van der Kraan PM, van den Berg WB (2006) Expression of transforming growth factor-beta (TGFbeta) and the TGFbeta signalling molecule SMAD-2P in spontaneous and instabilityinduced osteoarthritis: role in cartilage degradation, chondrogenesis and osteophyte formation. Ann Rheum Dis 65: 1414-1421

Cheng S, Lovett DH (2003) Gelatinase A (MMP-2) is necessary and sufficient for renal tubular cell epithelial-mesenchymal transformation. Am J Pathol 162: 1937 - 1949

Choi YH, Choi KC, Park YE (1997) Relationship of transforming growth factor beta 1 to angiogenesis in gastric carcinoma. J Korean Med Sci 12: $427-432$

Dallas SL, Rosser JL, Mundy GR, Bonewald LF (2002) Proteolysis of latent transforming growth factor-beta (TGF-beta)-binding protein-1 by osteoclasts. A cellular mechanism for release of TGF-beta from bone matrix. I Biol Chem 277: 21352-21360

D’Angelo M, Billings PC, Pacifici M, Leboy PS, Kirsch T (2001) Authentic matrix vesicles contain active metalloproteases (MMP). A role for matrix vesicle-associated MMP-13 in activation of transforming growth factorbeta. I Biol Chem 276: 11347-11353

Dasgupta S, Bhattacharya-Chatterjee M, O’Malley Jr BW, Chatterjee SK (2006) Tumor metastasis in an orthotopic murine model of head and neck cancer: possible role of TGF-beta 1 secreted by the tumor cells. J Cell Biochem 97: $1036-1051$

Derynck R, Akhurst RJ, Balmain A (2001) TGF-beta signaling in tumor suppression and cancer progression. Nat Genet 29: 117-129

Desruisseau S, Palmari J, Giusti C, Romain S, Martin PM, Berthois Y (2006) Determination of TGFbetal protein level in human primary breast cancers and its relationship with survival. $\mathrm{Br} J$ Cancer 94: $239-246$

Dwivedi DJ, Pino G, Banh A, Nathu Z, Howchin D, Margetts P, Sivak JG, West-Mays JA (2006) Matrix metalloproteinase inhibitors suppress transforming growth factor-beta-induced subcapsular cataract formation. Am J Pathol 168: 69-79
Ehrhart EJ, Segarini P, Tsang ML, Carroll AG, Barcellos-Hoff MH (1997) Latent transforming growth factor betal activation in situ: quantitative and functional evidence after low-dose gamma-irradiation. FASEB J 11: $991-1002$

Elliott RL, Blobe GC (2005) Role of transforming growth factor beta in human cancer. J Clin Oncol 23: 2078-2093

Ganesh S, Sier CF, Heerding MM, Griffioen G, Lamers CB, Verspaget HW (1994) Urokinase receptor and colorectal cancer survival. Lancet 344: $401-402$

George SJ, Johnson JL, Smith MA, Angelini GD, Jackson CL (2005) Transforming growth factor-beta is activated by plasmin and inhibits smooth muscle cell death in human saphenous vein. J Vasc Res 42: $247-254$

Hanemaaijer R, Visser H, Konttinen YT, Koolwijk P, Verheijen JH (1998) A novel and simple immunocapture assay for determination of gelatinase-B (MMP-9) activities in biological fluids: saliva from patients with Sjogren's syndrome contain increased latent and active gelatinase-B levels. Matrix Biol 17: 657-665

Jullien P, Berg TM, Lawrence DA (1989) Acidic cellular environments: activation of latent TGF-beta and sensitization of cellular responses to TGF-beta and EGF. Int J Cancer 43: 886-891

Kim HS, Shang T, Chen Z, Pflugfelder SC, Li DQ (2004) TGF-beta1 stimulates production of gelatinase (MMP-9), collagenases (MMP-1, -13) and stromelysins (MMP-3, -10, -11) by human corneal epithelial cells. Exp Eye Res 79: $263-274$

Kubben FJ, Sier CF, van Duijn W, Griffioen G, Hanemaaijer R, van de Velde CJ, van Krieken JH, Lamers CB, Verspaget HW (2006) Matrix metalloproteinase-2 is a consistent prognostic factor in gastric cancer. Br J Cancer 94: 1035 - 1040

Lyons RM, Gentry LE, Purchio AF, Moses HL (1990) Mechanism of activation of latent recombinant transforming growth factor beta 1 by plasmin. J Cell Biol 110: $1361-1367$

Maeda S, Dean DD, Gomez R, Schwartz Z, Boyan BD (2002) The first stage of transforming growth factor betal activation is release of the large latent complex from the extracellular matrix of growth plate chondrocytes by matrix vesicle stromelysin-1 (MMP-3). Calcif Tissue Int 70: $54-65$

Maehara Y, Kakeji Y, Kabashima A, Emi Y, Watanabe A, Akazawa K, Baba H, Kohnoe S, Sugimachi K (1999) Role of transforming growth factorbeta 1 in invasion and metastasis in gastric carcinoma. J Clin Oncol 17: $607-614$

Marek A, Brodzicki J, Liberek A, Korzon M (2002) TGF-beta (transforming growth factor-beta) in chronic inflammatory conditions-a new diagnostic and prognostic marker? Med Sci Monit 8: RA145-RA151

Massague J, Seoane J, Wotton D (2005) Smad transcription factors. Genes Dev 19: $2783-2810$

Mazzieri R, Jurukovski V, Obata H, Sung J, Platt A, Annes E, KaramanJurukovska N, Gleizes PE, Rifkin DB (2005) Expression of truncated latent TGF-beta-binding protein modulates TGF-beta signaling. J Cell Sci 118: $2177-2187$ 
Murphy-Ullrich JE, Poczatek M (2000) Activation of latent TGF-beta by thrombospondin-1: mechanisms and physiology. Cytokine Growth Factor Rev 11: $59-69$

Naef M, Ishiwata T, Friess H, Buchler MW, Gold LI, Korc M (1997) Differential localization of transforming growth factor-beta isoforms in human gastric mucosa and overexpression in gastric carcinoma. Int $J$ Cancer 71: $131-137$

Nakamura M, Katano M, Kuwahara A, Fujimoto K, Miyazaki K, Morisaki T, Mori M (1998) Transforming growth factor beta1 (TGF-beta1) is a preoperative prognostic indicator in advanced gastric carcinoma. $\mathrm{Br} \mathrm{J}$ Cancer 78: $1373-1378$

Park D, Son HJ, Song SY, Choe WH, Lim YJ, Park SJ, Kim JJ, Kim YH, Rhee PL, Paik SW, Rhee JC, Choi KW (2002) Role of TGF-beta 1 and TGF-beta type II receptor in gastric cancer. Korean J Intern Med 17: $160-166$

Park YE, Choi YH, Lee WY, Choi KC (1997) Transforming growth factor beta 1 expression in gastric carcinoma. J Korean Med Sci 12: $215-220$

Persson U, Izumi H, Souchelnytskyi S, Itoh S, Grimsby S, Engstrom U, Heldin CH, Funa K, ten Dijke P (1998) The L45 loop in type I receptors for TGF-beta family members is a critical determinant in specifying Smad isoform activation. FEBS Lett 434: $83-87$

Saito H, Tsujitani S, Oka S, Kondo A, Ikeguchi M, Maeta M, Kaibara N (1999) The expression of transforming growth factor-betal is significantly correlated with the expression of vascular endothelial growth factor and poor prognosis of patients with advanced gastric carcinoma. Cancer 86: $1455-1462$
Seomun Y, Kim J, Lee EH, Joo CK (2001) Overexpression of matrix metalloproteinase-2 mediates phenotypic transformation of lens epithelial cells. Biochem J 358: $41-48$

Sier CF, Casetta G, Verheijen JH, Tizzani A, Agape V, Kos J, Blasi F, Hanemaaijer R (2000) Enhanced urinary gelatinase activities (matrix metalloproteinases 2 and 9) are associated with early-stage bladder carcinoma: a comparison with clinically used tumor markers. Clin Cancer Res 6: 2333-2340

Sier CF, Kubben FJ, Ganesh S, Heerding MM, Griffioen G, Hanemaaijer R, van Krieken JH, Lamers CB, Verspaget HW (1996) Tissue levels of matrix metalloproteinases MMP-2 and MMP-9 are related to the overall survival of patients with gastric carcinoma. $\mathrm{Br}$ J Cancer 74: 413-417

Sier CF, Vloedgraven HJ, Ganesh S, Griffioen G, Quax PH, Verheijen JH, Dooijewaard G, Welvaart K, van de Velde CJ, Lamers CB (1994) Inactive urokinase and increased levels of its inhibitor type 1 in colorectal cancer liver metastasis. Gastroenterology 107: 1449-1456

Taipale J, Koli K, Keski-Oja J (1992) Release of transforming growth factorbeta 1 from the pericellular matrix of cultured fibroblasts and fibrosarcoma cells by plasmin and thrombin. J Biol Chem 267: 25378-25384

Tsushima H, Kawata S, Tamura S, Ito N, Shirai Y, Kiso S, Imai Y, Shimomukai H, Nomura Y, Matsuda Y, Matsuzawa Y (1996) High levels of transforming growth factor beta 1 in patients with colorectal cancer: association with disease progression. Gastroenterology 110: 375-382

Wang M, Zhao D, Spinetti G, Zhang J, Jiang LQ, Pintus G, Monticone R, Lakatta EG (2006) Matrix metalloproteinase 2 activation of transforming growth factor-betal (TGF-beta1) and TGF-betal-type II receptor signaling within the aged arterial wall. Arterioscler Thromb Vasc Biol 26: $1503-1509$ 